Türkyılmaz, M. B. ve Arı, B. (2021). Yaratıcı yazma etkinliklerinin ortaokul 7. sınıf öğrencilerinin öykü yazma becerilerine etkisi. Ana Dili Ĕgitimi Dergisi, 9(4), 1151-1168.

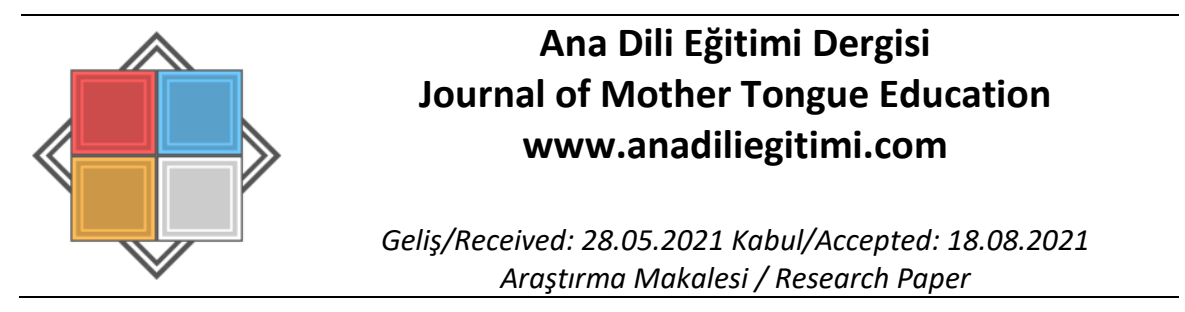

\title{
Yaratıcı Yazma Etkinliklerinin Ortaokul 7. Sınıf Öğrencilerinin Öykü Yazma Becerilerine Etkisi* $^{*}$
}

\author{
Mustafa Burak TÜRKYILMAZ** \\ Bülent $A R I^{* * *}$
}

\begin{abstract}
Öz
Bu çalışma yaratıcı yazma etkinliklerinin ortaokul 7. sınıf öğrencilerinin öykü yazma başarıları üzerindeki etkisini belirlemek amacıyla yapılmıştır. Araştırmanın çalışma grubunu 2019- 2020 öğretim yılında Hatay ili Antakya ilçesinde yer alan bir ortaokulda 7. sınıf düzeyinde öğrenim gören 67 öğrenci oluşturmaktadır. Ön test son test kontrol gruplu desenin kullanıldığı bu çalışmada deney grubunda 33, kontrol grubunda ise 34 öğrenci yer almaktadır. 12 hafta yürütülen çalışmada deney grubunda yaratıcı yazma etkinlikleri ile dersler yürütülürken kontrol grubunda ise mevcut ders kitabı etkinlikleri ile öğretim sürdürülmüştür. Ön test ve son test amacıyla öğrencilere belirlenen öykü konularından biri hakkında bir öykü yazmaları istenmiştir. Deney ve kontrol grubunda yer alan öğrencilerin ön test ve son testleri ise "Öykü Yazma Becerisi Ölçeği” doğrultusunda değerlendirilmiştir. Araştırmanın sonucunda deney grubundaki öğrencilerin son testte almış oldukları puanların ortalamalarının, kontrol grubunda yer alan öğrencilerin almış oldukları son test puanlarııı ortalamalarından anlamlı bir şekilde yüksek olduğu görülmüştür. Öykü Yazma Becerisi Ölçeği alt boyutlarında da deney grubundaki öğrencilerin puanları ile kontrol grubundaki öğrencilerin puanları arasında deney grubu lehine anlamlı bir fark olduğu belirlenmiştir. Bu sonuçlar doğrultusunda yaratıcı yazma etkinliklerinin öğrencilerin öykü yazma başarısında mevcut programda yer alan etkinliklere göre daha etkili olduğu söylenebilir. Öğrencilerin yazma becerilerine katkı sağlayabilecek olması nedeniyle ve bu durumun öğrencilerin yazmaya karşı tutumlarını olumlu etkileyebilecek olması nedeniyle yaratıı yazma etkinliklerinin ortaokul ders kitaplarında yer alması önerilebilir.
\end{abstract}

Anahtar Kelimeler: Yaratııı yazma, ortaokul öğrencileri, öykü yazma becerisi

\section{The Effects of Creative Writing Activities On the Writing Story Skills of 7th Grade Students}

\begin{abstract}
This research aims to investigate the effect of creative writing activities on the writing story skills of 7 th-grade students. The research sample includes 67 students who were 7 th grader in a secondary school in Antakya/Hatay in the 2019-2020 academic year. In this study, the pre-test post-test control group design was used. There were 33 students in the experimental group and 34 students in the control group. In the study, which was conducted for 12 weeks, while the lessons were carried out with creative writing activities in the experimental group, the teaching was
\end{abstract}

\footnotetext{
${ }^{*}$ Bu çalışma "Etkinlik Temelli Yaratıcı Yazma Çalışmalarının Yedinci Sınıf Öğrencilerinin Öykü Yazma Becerileri, Yazma Tutumları, Öz Düzenleme Stratejileri ve Motivasyonel İnançlarına Etkisi” başlıklı doktora tezinin bir bölümünden oluşmaktadır.

${ }^{* *}$ Arş. Gör. Dr., Hatay Mustafa Kemal Üniversitesi, Eğitim Fakültesi, Hatay, mburakturkyilmaz@gmail.com, ORCiD: orcid.org/0000-0002-2712-2273

*** Prof. Dr. Hatay Mustafa Kemal Üniversitesi, Eğitim Fakültesi, Hatay, bulentari01@gmail.com, ORCiD: orcid.org/0000-0002-7807-3660
} 
continued with the existing textbook activities in the control group. For the pre-test and post-test, the students were asked to write a story about one of the story topics determined. The pre-test and post-tests of the students in the experimental and control groups were evaluated in line with the "Story Writing Skills Scale". The finding showed that the average of the post-test scores of the students in the experimental group was significantly higher than the average of the post-test scores of the students in the control group. Similar results were obtained in the sub-dimensions of the Story Writing Skills Scale. Based on the research findings, it can be argued that creative writing activities might be more effective in students' story writing success than the activities in the current program. Creative writing activities could be included in secondary school textbooks since it may contribute to students' writing skills and may positively affect students' attitudes towards writing. Keywords: Creative writing, secondary school students, story writing skill

\section{Giriş}

"Yaratıcllı; yeni, özgün ve beceriye dayalı bir ürün olarak ortaya çıkmış veya henüz ürüne dönüşmemiş, kendine özgü bir problem çözme sürecini içeren, kişinin zekâ unsurlarını da özgün ve üretime dönük kullandığı bir bilişsel yetenektir" (Aslan, 2001, s. 20). Yaratıcılık bütün insanların belirli ölçüde sahip olduğu bilişsel bir beceridir (Davaslıgil, 1994, s. 53; Oral, 2014, s. 2; Sundt, 2018, s. 27). Ancak, her bireyde olduğu düşünülen bu becerinin düzeyi ve desteklenerek ortaya çıkarılma biçimleri bireyler arasında farklılık gösterebilmektedir (Fyle, 1985, s. 30; Kale, 1993, s. 27; Karakuş, 2001, s. 4; Oral, 2014, s. 2). Bu görüşler doğrultusunda yaratıcılık becerisinin hem doğal hem de yaşantılar ile beslenen bir beceri olduğunu ifade etmek mümkündür. Dolayısıyla az ya da çok olmakla birlikte her insanda var olduğu düşünülen bu beceri geliştirilebilir bir nitelik taşımaktadır (Ün-Açıkgöz, 2014, s. 137; Sönmez, 2017, s. 174). Bu aşamada ise eğitimin önemli bir rolü olduğu açıktır.

Yaratıcı yazma kavramı ise Oral $(2014$, s. 8) tarafından "kişinin bir konudaki duygu ve düşüncelerini hayal gücünü kullanarak özgürce kâğıda dökmesi" şeklinde tanımlanmaktadır. Aşılığlu (1993, s. 146) yaratıcı yazmanın, "dış dünyadan elde edilen izlenimlerin farklı bir sunumla ortaya konması" olduğunu ifade etmiştir. Sundt $(2018$, s. 15) ise yaratıcı yazmayı, yazarın bir metin oluşturmak için hayal gücünü kullandığı kurgu çalışmaları olarak tanımlamaktadır.

Yapılan tanımları incelediğimizde yaratıcı yazma kavramının, var olan bilgilerin bireyler tarafından belirli bilişsel süreçlerin kullanılması sonucu ortaya koydukları özgün ürünler olduğu çıkarımını yapmaktayız. Özgün ürünler ortaya koyulmasında en önemli kavramlardan biri ise "kurgu" dur. Bireyde yaşantılar sonucu var olan bilgilerin hayal gücü doğrultusunda özgün bir şekilde yeniden oluşturulması, kurgulama sonucunda ortaya çıkan bir üründür.

Göğüş $(1978$, s. 265) öğrencilere kazandırılacak olan yazma becerilerini iş yazıları, bilgi ve düşünce yazıları ve yaratıcı yazılar başlıklarında sınıflandırmıştır. Yaratıcı yazıların kapsamında kabul edilebilecek metin türlerinin öykü, roman, anı, şiir, deneme, tiyatro gibi türleri kapsadığı ifade edilmektedir (Göğüş,1978, s. 64; Aktaş, 2009, s. 98). Harper (2010) şiir, hikâye, roman türlerinin yaratıcılığa daha çok yer verilebilecek metin türleri olduğunu ifade etmiştir (Erdoğan, 2012, s. 40). Temizkan (2011, s. 921), kurmaca metnin unsurlarının ön plana çıkarılabilecek metin türlerinin öykü, roman ve masal olduğunu ifade etmiştir. Bu bilgiler kapsamında yaratıcı yazma kavramını metin türlerinden bağımsız olarak ele almanın mümkün olamayacağını ifade edebiliriz. Yukarıda ifade edilen metin türlerinden öykü, roman kadar uzun olmamasından ve masal kadar olağanüstü öğeleri içinde barındırmamasından dolayı öğrencilerin yaratıcı yazma etkinliklerinde uygulanabilecek en uygun tür olarak karşımıza çıkmaktadır (Temizkan, 2011, s. 922).

19. yüzyılın sonları ve 20. yüzyılın başlarında Harvard Üniversitesi'ndeki kompozisyon çalışmaları yaratıcı yazma örnekleri arasında yer alan çalışmalar olmuştur (Myers, 1993, s. 283). 20. yüzyılda bu konuda meydana gelen gelişmeler sonucunda 1980 'li yıllardan sonra yaratıcı yazma gibi yaratıc yöntemlerle yapılan çalışmalar ve bu doğrultuda hazırlanan kitaplar ortaya çıkmışırı (İpşiroğlu, 2006, s. 9; Oral, 2014, s. 25). Ülkemizde yaratıcılık kavramına 1924 ikinci Kademe Türkçe Programı́nda yer verilmiş olmakla birlikte yaratıcı yazma bir yöntem olarak ilk kez 2005 Türkçe Öğretim Programı ve Kılavuzu'nda yer almıştır (Duru, 2014, s. 41). 2005 yılından itibaren eğitim sistemimizde etkili olan yapılandırmacı yaklaşım; yeni bilgilerin, öğrencilerin ön bilgilerinin üzerine inşa edildiğini ve bu süreçte öğrencilerin aktif olduğunu ileri sürmektedir. Öğrencilerin deneyimleri sonucu edindikleri bilgilerin 
üzerine hayal güçlerini etkin bir şekilde kullanarak özgün ürünler ortaya koydukları yaratıcı yazma ürünlerinin de bu süreçte etkili olabileceğini ifade etmek mümkündür.

Yaratıcı yazmanın bilişsel, sosyal ve psikolojik birçok katkısından söz etmek mümkündür. Oral (2003) yaratıcı yazma etkinliklerinin bireylerin soyutlama, sentez yapma, yorumlama gibi bilişsel becerilerine katkı sağladığını ifade etmektedir (Akt: Avcı, 2013, s. 19-20). Yaratıcı yazma bireylerin olayları sorgulamalarını, eleştirel düşünme becerilerini ve olay ve düşünceleri farklı bakış açısı ile ele almalarını sağlar (Susar Kırmızı ve Beydemir, 2012, s. 320). Bunun yanında bireylerin özgüven kazanmalarına ve bunun sonucunda yazma kaygılarının ortadan kalkmasına katkıda bulunur (Werder, 2000'den akt: Küçük, 2020, s. 54). Yaratıcı yazma etkinlikleri öğrencilerin kendi düşüncelerini özgürce dile getirmeleri yanında başkalarının duygu ve düşüncelerine saygı göstermeleri alışkanlığı kazanmalarına da yardımcı olmaktadır (Oral, 2014, s. 21). Temizkan (2010, s. 629), yaratıcı yazma etkinliklerinin öğrencilerin iç dünyalarının anlaşılabilmesinde etkili olduğunu ifade etmiştir. Akdal $(2011$, s. 29) yaratıcı yazma çalışmalarının yazma becerilerini geliştirmesinin yanı sıra öğrencilerin okuma isteklerini de olumlu yönde etkileyeceğini ifade etmiştir.

Yurt içi ve yurt dışında yapılmış olan çalışmaların büyük bir bölümünde yaratıcı yazma çalışmalarının bireylerin yazma becerilerini olumlu yönde etkilediği belirlenmiştir. Bununla birlikte yaratıcı yazma çalışmalarının öğrencilerin yazmaya yönelik ilgilerini artırmakta ve akademik başarılarına katkıda bulunmada etkili olduğu görülmüştür (Ak, 2011; Beydemir, 2010; Duran, 2010; Erdoğan, 2012; Korkmaz, 2015; Öztürk, 2007; Colantone vd., 1998; Dalavi ve Deshpande, 2018; Burkšaitienè, 2014). Bu çalışmalar arasında 7. sınıf düzeyinde yapılmış bir çalışmaya rastlanmamıştır. Bu araştırmanın sonuçları doğrultusunda, yaratıcı yazma çalışmalarının ortaokul 7. sınıf düzeyindeki etkilerinin incelenmesi ve diğer çalışmalardan elde edilen sonuçlarla birlikte değerlendirilmesi önem taşımaktadır.

Öğrencilerin dili daha etkili olarak kullanmalarını sağlayacak ve yazma uygulamalarındaki sorunların çözümüne seçenek olabilecek bir yöntem olarak gösterilen yaratıcı yazma çalışmalarııın öğretim program ve materyallerinde etkili bir şekilde kullanılması önem taşımaktadır (Maltepe 2006, s. 6-7). ilerleyen yaşlarda yaratıcılık becerisinin zayıflaması söz konusudur (Bulut, 2012, s. 64). Bundan dolayı öğretim sürecinin erken dönemlerinde öğrencilerin yaratıcı özeliklerini aktif halde kullanabilecekleri ve geliştirebilecekleri etkinliklere yer vermek gerekmektedir. Bu bağlamda ortaokul düzeyindeki öğrenciler üzerinde bu çalışmaların yapılmasının önem taşıdığı söylenebilir.

Araştırmanın amacı ortaokul 7. sınıf düzeyinde yaratıcı yazma etkinliklerinin öğrencilerin öykü yazma becerileri üzerindeki etkisini incelemektir. Bu amaç doğrultusunda araştırmanın alt problemleri şu şekildedir:

1. Ortaokul 7. sınıf düzeyinde yaratıcı yazma etkinlikleri ile öğrenim gören öğrencilerle mevcut programdaki etkinliklerle öğrenim gören öğrencilerin Öykü Yazma Becerisi Ölçeği son testinden aldıkları puanların arasında istatistiksel olarak anlamlı bir fark var mıdır?

2. Ortaokul 7. sınıf düzeyinde yaratıcı yazma etkinlikleri ile öğrenim gören öğrencilerin Öykü Yazma Becerisi Ölçeği ön test-son test puanlarının ortalamaları arasında istatistiksel olarak anlamlı bir fark var mıdır?

3. Ortaokul 7. sınıf düzeyinde mevcut programdaki etkinliklerle öğrenim gören öğrencilerin Öykü Yazma Becerisi Ölçeği ön test-son test puanlarının ortalamaları arasında istatistiksel olarak anlamlı bir fark var mıdır?

4. Ortaokul 7. sınıf düzeyinde yaratıcı yazma etkinlikleri ile öğrenim gören öğrencilerin cinsiyet değişkenine göre Öykü Yazma Becerisi Ölçeği ön test-son test puanlarının ortalamaları arasında istatistiksel olarak anlamlı bir fark var mıdır?

Yapılan bu araştırmanın yaratıcı yazma etkinliklerinin öğrencilerin öykü yazma becerileri üzerindeki etkisinin belirlenmesi ve öğretim sürecinde bu etkinliklerin daha etkili bir şekilde uygulanabilmesine katkı sağlayacağı düşünülmektedir. Ortaokul düzeyinin, öğrencilerin yaratıcılık becerilerini geliştirmeleri için önemli bir düzey olması nedeniyle bu çalışmanın sonuçlarının benzer çalışmaların sonuçları ile değerlendirilmesi önem taşımaktadır. 


\section{Araştırmanın Modeli}

\section{Yöntem}

Araştırma deneysel desenlerden ön test-son test kontrol gruplu desen modeli ile yapılmış bir çalışmadır. Bu modelde önceden belirlenmiş denek havuzundan oluşturulan iki gruptan biri deney diğeri ise kontrol grubu olarak belirlenir. Uygulama öncesinde her iki grubun bağımlı değişkene ilişkin ölçümleri yapıldıktan sonra deney grubuna ilgili deneysel işlem uygulanır. Uygulama sonunda ise her iki gruptaki bağımlı değişkene ilişkin ölçümler yapılır (Büyüköztürk vd., 2016, s. 205).

\section{Örneklem / Araştırma grubu}

Araştırmanın çalışma grubunu Hatay ili Antakya ilçesinde bir ortaokulda 2019-2020 eğitim öğretim yılı birinci yarıyılında öğrenim gören 7. sınıf öğrencileri oluşturmuştur. Araştırmada yer alan 67 öğrencinin 33'ü deney grubunda 34'ü ise kontrol grubunda yer almıştır. Deney grubunda yer alan öğrencilerin 19'u kız, 14'ü ise erkektir. Kontrol grubunda ise 17 kız 17 erkek öğrenci yer almıştır.

Araştırmada küme rastgele örnekleme yöntemi kullanılmıştır. Bu yöntem evrenden basit ve tabakalı rastgele örneklemenin zor olduğu durumlarda deneklerinin rastgele seçilerek deney ve kontrol grubuna atanması yerine ilgili grupların veya kümelerin seçilmesinin gerçekleştirilmesidir (Fraenkel, Wallen ve Hyun, 2012, s. 95-96). Bu kapsamda 7. sınıf düzeyinde öğrenim gören iki farklı şubede yer alan öğrencilerden belirlenen öykü yazma konularından biri hakkında yazdıkları öyküler değerlendirilmiştir. Yapılan ön test sonuçlarında deney ve kontrol grubunda yer alan öğrencilerin Öykü Yazma Becerisi Ölçeği toplam puanları arasında anlamlı bir farklılık olmadığı görülmüştür $\left[\mathrm{t}_{(65)}=-1,434\right.$, p>0.05]. Bununla birlikte deney ve kontrol grubunda yer alan öğrencilerin Öykü Yazma Becerisi Ölçeği alt boyutlarındaki ön test puanları da incelenmiştir. Alt boyutların tamamında deney ve kontrol grubu öğrencilerinin ön testleri arasında anlamlı bir fark olmadığı belirlenmiştir. Bu durum uygulama öncesinde her iki grubun öykü yazma becerilerinin benzer düzeyde olduğunu göstermektedir.

\section{Veri Toplama Araçları \\ Öykü Yazma Becerisi Ölçeği}

“Öykü Yazma Becerisi Ölçeği “Temizkan (2011) tarafından geliştirilmiştir. Ölçek; içerik, planlama, karakter, mekân ve zaman olmak üzere beş alt boyuttan oluşmuştur. İçerik boyutu; ana olay, yan olaylar, tema, tez, ana düğümler, ara düğümler unsurlarından oluşmaktadır. Planlama boyutu serim, düğüm ve çözüm unsurlarını içermektedir. Karakter boyutunda ana kahraman, hasım kahraman, yardımcı kahraman, kahraman tasvirleri, fiziksel çatışma ve psikolojik çatışma unsurları yer almaktadır. Mekân boyutu, mekân kullanımı ile mekân tasvirleri unsurlarını içermektedir. Zaman boyutunda ise zamanın kullanımı ve geriye dönüş unsurları yer almıştır. Ölçeğin geçerlik çalışması için uzman görüşüne başvurulmuştur. Ölçeğin güvenirlik çalışması ise araştırmacı ve 1 Türkçe öğretmeni tarafından 20 öykünün değerlendirilmesi ve bu değerlendirmeler arasındaki ilişkilerin Pearson Korelasyon Analizi ile belirlenmesi ile gerçekleştirilmiştir. Yapılan analizler sonucunda puanlayıcılar arası Pearson Korelasyon katsayıları içerik boyutu için .86, planlama boyutu için .93, karakter boyutu için .83 , mekan boyutu için .91 , zaman boyutu için .88 olarak hesaplanmıştır.

\section{İşlem / Verilerin Toplanması}

Çalışmada öğrencilerin ön test ve son testte öykü yazmaları için literatürde yapılmış çalışmaların (Yılmaz, 2012; Yasul, 2014; Yılmaz 2008; Çoban, 2012; Kılıç, 2012) incelenmesi sonucunda 11 adet öykü yazma konusu belirlenmiştir. Bu 11 öykü yazma konusu için 3 alan uzmanı görüşüne başvurulmuştur. Uzman görüşü sonucunda 4'er öykü konusunun ön test ve son testte kullanılması uygun görülmüştür. Deney ve kontrol grubunda yer alan öğrencilere belirlenen ön test öykü konuları dâhilinde bir öykü yazmaları istenmiştir. Uzman görüşü doğrultusunda belirlenen öykü yazma konuları Tablo 1'de görülmektedir. 
Tablo 1.

Öykü Yazma Becerisi Kapsamında Belirlenen Ön Test - Son Test Öykü Yazma Konuları

\section{Öykü Konuları}

\begin{tabular}{|c|c|}
\hline \multirow{4}{*}{$\begin{array}{l}\sqrt[5]{\breve{r}} \\
z \\
: 0\end{array}$} & $\begin{array}{l}\text { Babası Aylin'e yıl sonunda notlarının iyi olması durumunda bir } \\
\text { hediyesi olacağını söylemiştir. Yıl sonunda notları iyi olan Aylin'e } \\
\text { babası tarafından alınan hediye hakkında bir hikâye yazınız. }\end{array}$ \\
\hline & $\begin{array}{l}\text { Sevdiğiniz bir sanatçı ile tanışıp bir gün geçirdiğinizi düşünün. Bu } \\
\text { bir günü anlatan bir hikâye yazınız. }\end{array}$ \\
\hline & $\begin{array}{l}\text { Sokakta bulduğu bir köpek yavrusunu eve götüren Metin'in bu } \\
\text { davranışına karşı çıkacağını düşündüğünden dolayı babasından } \\
\text { saklamaya çalışması sonucu olanları anlatan bir hikâye yazınız. }\end{array}$ \\
\hline & $\begin{array}{l}\text { Kendinizi dağ başında bir ağaç olarak düşünüp hissettiklerinizi ve } \\
\text { yaşayabileceklerinizi anlatan bir öykü yazınız. }\end{array}$ \\
\hline \multirow{7}{*}{$\begin{array}{l}\mathfrak{n} \\
\mathfrak{H} \\
z \\
\text { ○ }\end{array}$} & $\begin{array}{l}\text { Ağaçta mahsur kalan bir yavru kediye yardım eden Merve'nin } \\
\text { yaşadığı olayı anlatan bir hikâye yazınız. }\end{array}$ \\
\hline & $\begin{array}{l}\text { Bir grup arkadaşın piknik için ormana gittikleri bir gün başından } \\
\text { geçenleri anlatan bir hikâye yazınız. }\end{array}$ \\
\hline & $\begin{array}{l}\text { Ailesinin ekonomik durumu iyi olmadığı için okul dışında çalışmak } \\
\text { zorunda olan } 13 \text { yaşındaki bir çocuğu anlatan bir hikâye yazınız. }\end{array}$ \\
\hline & $\begin{array}{l}\text { İleride yapmak istediğiniz meslekte çalıştığınızı düşünün. Bu } \\
\text { meslekte yaşayabileceğiniz sıra dışı bir olayı anlatan bir hikâye } \\
\text { yazınız. }\end{array}$ \\
\hline & Annenizin hafta sonu bir gününü anlatan bir hikâye yazınız. \\
\hline & $\begin{array}{l}\text { Yaz tatilinde en fazla aklınızda kalan (veya sizi en fazla mutlu } \\
\text { eden/heyecanlandıran) günü (olayı) anlatan bir hikâye yazınız. }\end{array}$ \\
\hline & $\begin{array}{l}\text { Hafta sonu babası ile sahilde balık tutmaya giden Oğuz'un } \\
\text { başından geçenleri anlatan bir hikâye yazınız. }\end{array}$ \\
\hline
\end{tabular}

MEB Talim ve Terbiye Kurulu Başkanlığı'nın kararı ile 2018-2019 eğitim öğretim yııında ortaokullarda okutulacak olan ders kitapları içinde yer alan ve Milli Eğitim Bakanlığı Yayınları tarafından basılan 4 adet 7. sınıf Türkçe ders kitabı incelenmiştir. Uygulama sürecinde yürütülecek olan dersler, bu kitaplarda yer alan öyküleyici metinlerden seçilen örnekler doğrultusunda hazırlanmıştır. Kontrol gurubundaki dersler ilgili kitaplardaki etkinlikler doğrultusunda hazırlanan ders planları kapsamında yürütülmüştür. Deney grubundaki dersler ise literatürde (Donovon, 2012; May, 2013; Morley, 2010; İşiroğlu, 2006) yaratıcı yazarlık kapsamında uygulanabilecek etkinliklerin incelenmesi sonucunda oluşturulan etkinliklerle hazırlanan ders planları ile yürütülmüştür. Uygulama süreci haftada 2 ders saati olmak üzere 12 hafta devam etmiştir. Uygulama sürecindeki haftalık etkinliklerin süresi ve öykü yazma becerisi ölçeği alt boyutlarına yönelik dağııımı Tablo 2'de görülmektedir.

Tablo 2.

Deney Grubunda Uygulanan Etkinliklerin Öykü Yazma Becerisi Ölçeği Alt Boyutlarına Yönelik Dağılımı

\begin{tabular}{|c|c|c|c|c|}
\hline \multicolumn{5}{|c|}{ Deney Gurunda Yapılan Etkinliklerin Öykü Elementleri Bakımından Dağılımı } \\
\hline $\begin{array}{l}\text { Öykü Yazma } \\
\text { Becerisi Ölçeği } \\
\text { Alt Boyutları }\end{array}$ & Metin & $\begin{array}{l}\text { İlgili } \\
\text { Etkinlikler }\end{array}$ & Süre & Açıklama \\
\hline & $\begin{array}{l}\text { Tahta } \\
\text { Bisiklet }\end{array}$ & $\begin{array}{l}\text { Etkinlik } 1 \\
\text { Etkinlik } 2\end{array}$ & & $\begin{array}{l}\text { a. Okunan metnin konusu ve temasını } \\
\text { belirleme }\end{array}$ \\
\hline İçerik & $\begin{array}{l}\text { Pembe Incili } \\
\text { kaftan }\end{array}$ & Etkinlik 4 & $2 \mathrm{Haft}$ & $\begin{array}{l}\text { b. Verilen bir konu üzerinde temayı } \\
\text { belirleyerek öykü oluşturma }\end{array}$ \\
\hline
\end{tabular}




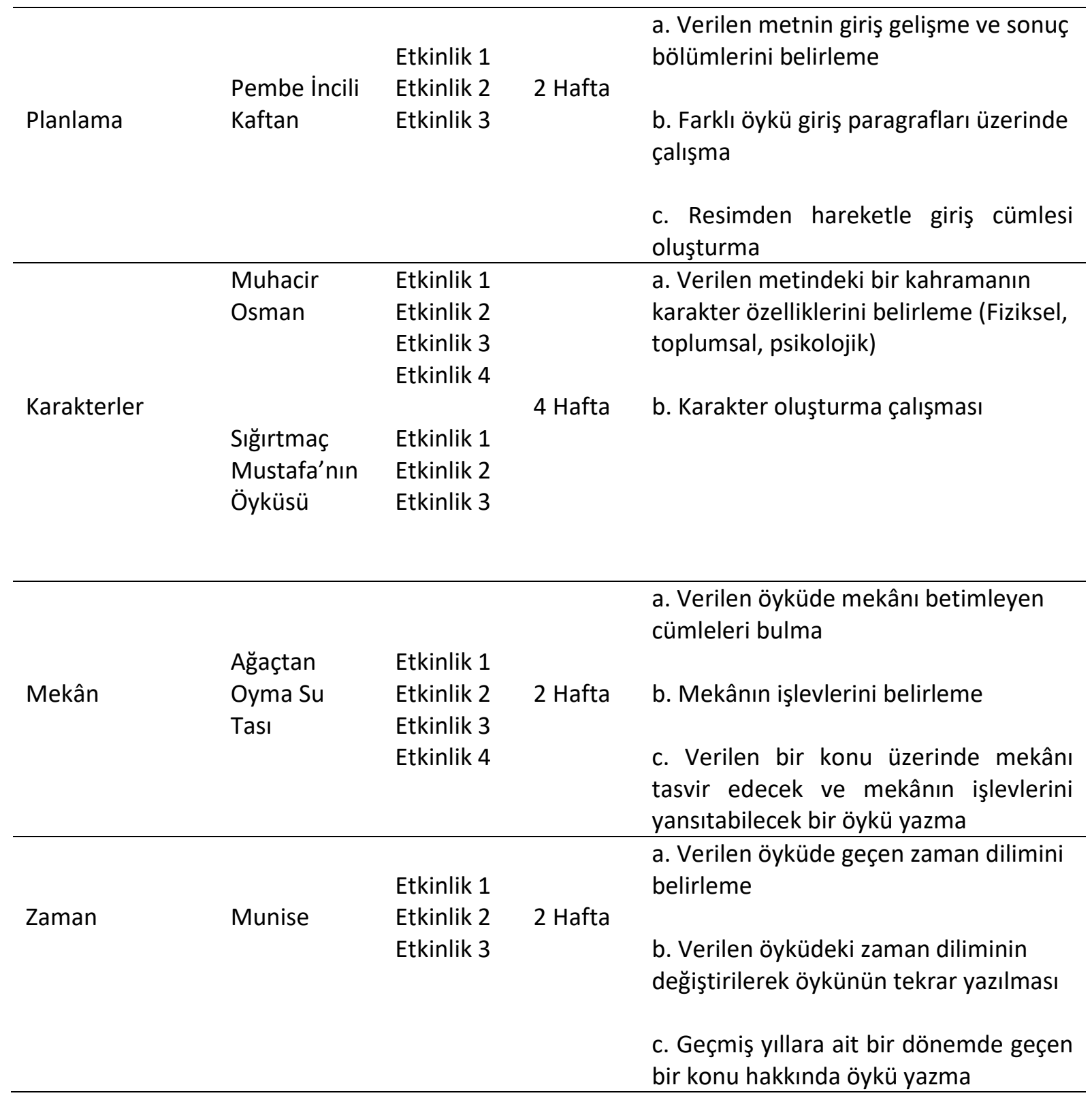

Uygulama sonunda deney ve kontrol grubundaki öğrencilerden son testte öykü konuları olarak belirlenen 4 öykü konusundan biri hakkında bir öykü yazmaları istenmiş̧ir. Uygulama sonunda elde edilen veriler analiz edilerek değerlendirilmiştir.

\section{Verilerin Analizi}

Deney grubu ile kontrol grubu arasındaki ön test puanlarının istatistiksel analizlerinde Bağımsız Örneklem t Testi ve Mann Whitney U testleri kullanılmıştır. Deney grubu ile kontrol grubunun son test puanlarının analizinde ise karışık ölçümler için Iki Faktörlü Varyans Analizi uygulanmıştır.

Deney grubu ile kontrol grubunun kendi içlerindeki ön test-son test puanlarının analizi ise iliş̧kili Örneklem t Testi ve Wilcoxon İşaretli Sıralar Testi ile analiz edilmiştir.

Çalışmaya ilişkin verilerin analiz edilmesi bakımından öncelikle deney ve kontrol grubunda yer alan öğrencilerin ön test ve son test puanlarının normal dağııım gösterip göstermediği incelenmiştir.

Basıklık ve çarpıklık değerleri verilerin normal dağılım göstermelerinin incelendiği değerlerdendir. Çarpıklık ve basıklık değerlerinin +2 ve -2 arasında olması verilerin normal dağılım gösterdiği şeklinde yorumlanabilir (George ve Mallery, 2020, s. 114-115). Bu bağlamda deney grubu ön testi ile kontrol grubu son testinde zaman alt boyutunda elde edilen verilerin normal dağılım 
göstermediği belirlenmiştir. Deney grubu ve kontrol grubunda yer alan öğrencilerin ön test ve son test verilerinde içerik, planlama, karakter, mekân alt boyutları ile toplam puanlara ait verilerin ise normal dağılım gösterdiği görülmüştür.

\section{Geçerlik ve Güvenirlik}

Lisans öğrencileri üzerinde uygulanması amacıyla geliştirilen bu ölçeğin maddeleri, ortaokul 7. sınıf düzeyinde geçerlik çalışması kapsamında Türkçe Eğitimi alanında uzman olan 3 öğretim elemanının görüşüne sunulmuştur. Uzman görüşü doğrultusunda karakter alt boyutunda; hasım karakter, fiziksel çatışma ve psikolojik çatışma alt boyutları ile zaman boyutunda yer alan geriye dönüş alt boyutunun 7. sınıf düzeyi için uygun olmaması nedeniyle ilgili ölçme aracından çıkarılmasının uygun olduğu görüşüne varılmıştır. Bu bağlamda ölçme aracı 5 temel boyut ve ilgili 15 alt boyut kapsamında kullanılmıştır.

Ölçme araçlarının güvenirliğini belirlemek amacıyla kullanılan yöntemlerden biri puanlayıcı güvenirliğidir. Puanlayıcı güvenirliği; iki ya da daha fazla puanlayıcının farklı bireylere ve farklı maddelere ilişkin yaptıkları puanlamalar arasındaki tutarlıı̆ın derecesidir (Kan, 2018, s. 70). Kappa istatistiği ve sınıf içi korelasyon katsayıları iki puanlayıcının puanları arasındaki güvenirliği belirlemek için kullanılan yöntemlerdendir.

İlgili ölçme aracının güvenirlik çalışması kapsamında ortaokul 7. sınıf öğrencilerinden oluşan 84 kişiye verilen 4 öykü konusundan herhangi birini seçerek bir öykü yazmaları istenmiştir. Uygulama sonucunda öğrencilerin yazdıkları öyküler ilgili ölçme aracı doğrultusunda iki alan uzmanı tarafından değerlendirilerek puanlandırılmıştır. Yapılan değerlendirmeler arasındaki uyum katsayıları aşağıdaki tabloda görülmektedir.

Tablo 3.

Öykü Yazma Becerisi Ölçeğine Ait Puanlayıcılar Arası Uyum Katsayıları

\begin{tabular}{|c|c|c|c|c|c|}
\hline & $\begin{array}{l}\text { Puanlama } \\
\text { Anahtarının } \\
\text { Kategorileri }\end{array}$ & $\begin{array}{l}\text { Puanlayıcı } \\
\text { Ortalamaları } \\
\text { (Puanlayıcı 1) }\end{array}$ & $\begin{array}{l}\text { Puanlayıcı } \\
\text { Ortalamaları } \\
\text { (Puanlayıcı 2) }\end{array}$ & $\begin{array}{l}\text { Sınıf İçi } \\
\text { Korelasyon } \\
\text { İstatistiği } \\
\text { Değeri }\end{array}$ & $\begin{array}{l}\text { Kappa } \\
\text { İstatistiği } \\
\text { Değeri }\end{array}$ \\
\hline & $\begin{array}{ll}\begin{array}{l}\text { Ana } \\
\text { (Konu) }\end{array} & \text { Olay }\end{array}$ & 2,53 & 2,52 & 0,69 & 0,68 \\
\hline \multirow[t]{5}{*}{ İÇERIK } & Yan Olaylar & 2,05 & 2,20 & 0,81 & 0,63 \\
\hline & Tema (izlek) & 2,23 & 2,32 & 0,74 & 0,70 \\
\hline & $\begin{array}{ll}\text { Tez (Ana } \\
\text { Düsünce) }\end{array}$ & 2,16 & 2,38 & 0,51 & 0,51 \\
\hline & Ana Düğüm & 1,88 & 2,15 & 0,66 & 0,53 \\
\hline & Ara Düğümler & 1,69 & 1,84 & 0,75 & 0,64 \\
\hline \multirow[t]{3}{*}{ PLANLAMA } & Serim Bölümü & 2,46 & 2,40 & 0,73 & 0,63 \\
\hline & Düğüm Bölümü & 2,02 & 2,32 & 0,69 & 0,51 \\
\hline & Çözüm Bölümü & 1,98 & 2,14 & 0,76 & 0,74 \\
\hline \multirow[t]{3}{*}{ KARAKERLER } & Ana Karakter & 2,52 & 2,67 & 0,62 & 0,66 \\
\hline & $\begin{array}{l}\text { Yardımcı } \\
\text { Karakter }\end{array}$ & 2,03 & 2,08 & 0,85 & 0,71 \\
\hline & $\begin{array}{l}\text { Karakter } \\
\text { Tasvirleri }\end{array}$ & 1,70 & 1,61 & 0,67 & 0,71 \\
\hline \multirow[t]{2}{*}{ MEKÂN } & Mekân & 2,40 & 2,40 & 0,81 & 0,71 \\
\hline & $\begin{array}{l}\text { Mekân } \\
\text { Tasvirleri }\end{array}$ & 1,86 & 1,69 & 0,71 & 0,54 \\
\hline ZAMAN & Zaman & 2,28 & 2,19 & 0,62 & 0,47 \\
\hline
\end{tabular}


"Öykü Yazma Becerisi Ölçeği” güvenirlik çalışması kapsamında maddelere ilişkin elde edilen sınıf içi korelasyon değerlerinin 0,51 ile 0,85 arasında değiştiği belirlenmiştir. Sınıf içi korelasyon değerinin 1'e yakın olması güvenirliğin yüksek olduğunu belirtmektedir. Ölçme aracındaki maddeler arasındaki Kappa değerlerinin ise 0,47 ile 0,74 arasında değiştiği görülmektedir.

Bu sonuçlar doğrultusunda her iki puanlayıcının puanlamaları arasında ölçme aracında yer alan hiçbir maddede düşük düzeyde uyum gözlemlenmemiştir Bu sonuçlar, ilgili ölçme aracını çalışmamız kapsamında ilgili sınıf düzeyi doğrultusunda kullanabileceğimizi göstermektedir.

\section{Araştırma ve Yayın Etiği}

Bu çalışmada "Yükseköğretim Kurumları Bilimsel Araştırma ve Yayın Etiği Yönergesi" kapsamında uyulması belirtilen tüm kurallara uyulmuştur. Yönergenin ikinci bölümü olan "Bilimsel Araştırma ve Yayın Etiğine Aykırı Eylemler" başlığı altında belirtilen eylemlerden hiçbiri gerçekleştirilmemiştir.

\section{Birinci Alt Probleme ilişkin Bulgular}

\section{Bulgular}

Yapılan uygulama sonucunda yaratıcı yazma etkinlikleri ile hazırlanan ders planları doğrultusunda yürütülen uygulamanın öğrenciler üzerinde etkili olup olmadığını sınamak amacıyla karışık ölçümler için iki faktörlü varyans analizi yapılmıştır. Yapılan analiz sonucunda yer alan betimsel veriler ve varyans analizi sonuçları aşağıdaki tablolarda görülmektedir. Yapılan karışık ölçümler için iki faktörlü varyans analizi sonuçlarında karakter ve zaman alt boyutlarında analiz için gerekli varsayımların sağlanmadığı görülmüştür. Bundan dolayı bu iki alt boyut için bu desende kullanılabilecek diğer bir analiz olan ön test-son test puanları arasındaki farkların t testi analizi yapılmıştır.

Tablo 4.

Deney Grubu- Kontrol Grubu Son Test Puanlarına ilişkin Ortalama ve Standart Sapma Değerleri

\begin{tabular}{llcccccc}
\hline BOYUTLAR & GRUPLAR & \multicolumn{3}{c}{ ÖN TEST } & \multicolumn{3}{c}{ SON TEST } \\
\hline \multirow{2}{*}{ içerik } & & $\mathrm{n}$ & $\overline{\mathrm{X}}$ & ss & $\mathrm{n}$ & $\overline{\mathrm{X}}$ & SS \\
& Deney G. & 33 & 1,70 & 0,59 & 33 & 2,65 & 0,36 \\
& Kontrol G. & 34 & 1,91 & 0,50 & 34 & 2,08 & 0,34 \\
\hline Planlama & Deney G. & 33 & 1,86 & 0,64 & 33 & 2,78 & 0,38 \\
& Kontrol G. & 34 & 2,07 & 0,58 & 34 & 2,11 & 0,40 \\
\hline \multirow{2}{*}{ Mekân } & Deney G. & 33 & 1,37 & 0,39 & 33 & 2,34 & 0,53 \\
& Kontrol G. & 34 & 1,33 & 0,34 & 34 & 1,60 & 0,57 \\
\hline \multirow{2}{*}{ Toplam } & Deney G. & 33 & 1,65 & 0,43 & 33 & 2,58 & 0,31 \\
& Kontrol G. & 34 & 1,79 & 0,36 & 34 & 1,90 & 0,24 \\
\hline
\end{tabular}

Tablo 4'te deney ve kontrol grubu öğrencilerinin son test puanlarına ilişkin betimsel veriler belirtilmiştir. Öğrencilerin Öykü Yazma Becerisi Ölçeği toplam puanları ve ilgili alt boyutlarına ait puanlar incelendiğinde son test puanlarının ortalamalarının daha yüksek olduğu görülmektedir. Bu sonuçlara yönelik ANOVA sonuçları Tablo 5'de incelenmiştir.

Tablo 5.

Deney Grubu - Kontrol Grubu Son Test Toplam Puanlarına ilişsin ANOVA Sonuçları

\begin{tabular}{|c|c|c|c|c|c|c|}
\hline Varyansın Kaynağı & KT & & sd & KO & $\mathbf{F}$ & p \\
\hline Deneklerarası & 13,493 & 66 & & & & \\
\hline Grup (Birey/Grup) & 2,452 & & 1 & 2,452 & 14,435 & 0,000 \\
\hline Hata & 11,041 & & 65 & 0,170 & & \\
\hline Denekleriçi & 19,254 & 67 & & & & \\
\hline $\begin{array}{l}\text { Ölçüm (Ön test-Son } \\
\text { test) }\end{array}$ & 8,845 & & 1 & 8,845 & 121,398 & 0,000 \\
\hline
\end{tabular}




\begin{tabular}{|c|c|c|c|c|c|c|c|}
\hline Grup*Ölçüm & & 5,673 & & 1 & 5,673 & 77,857 & 0,000 \\
\hline Hata & & 4,736 & & 65 & 0,073 & & \\
\hline Toplam & 32,747 & & 133 & & & & \\
\hline
\end{tabular}

Tablo 5’e göre Öykü Yazma Becerisi Ölçeği son test toplam puanları incelendiğinde deney grubunda yer alan öğrencilerin puanlarının, kontrol grubunda yer alan öğrencilerin puanlarına göre anlamlı düzeyde yüksek olduğu görülmektedir $\left[F_{(1-65)}=77,857, p<0.01\right]$. "Öykü yazma Becerisi Ölçeği”" alt boyutlarına ait bulgular aşağıdaki tablolarda değerlendirilmiştir.

Tablo 6.

Deney Grubu - Kontrol Grubu Içerik Alt Boyutuna Ait Son Test Puanlarına ilişskin ANOVA Sonuçları

\begin{tabular}{|c|c|c|c|c|c|c|}
\hline Varyansın Kaynağı & KT & & sd & KO & $\mathbf{F}$ & $\mathbf{p}$ \\
\hline Deneklerarası & 19,823 & 66 & & & & \\
\hline Grup (Birey/Grup) & 1,027 & & 1 & 1,027 & 3,550 & 0,064 \\
\hline Hata & 18,796 & & 65 & 0,289 & & \\
\hline Denekleriçi & 24,599 & 67 & & & & \\
\hline $\begin{array}{l}\text { Ölçüm (Ön test-Son } \\
\text { test) }\end{array}$ & 10.480 & & 1 & 10,480 & 75,224 & 0,000 \\
\hline Grup*Ölçüm & 5,063 & & 1 & 5,063 & 36,339 & 0,000 \\
\hline Hata & 9,056 & & 65 & 0,139 & & \\
\hline Toplam & 44,422 & 133 & & & & \\
\hline
\end{tabular}

Yukarıdaki tabloda "Öykü Yazma Becerisi Ölçeği" içerik alt boyutu son test puanlarına yönelik bulgular yer almaktadır. İçerik alt boyutuna yönelik elde edilen bulgular, uygulama sonunda deney grubu ile kontrol grubu arasında deney grubu lehine anlamlı bir fark olduğunu göstermektedir $\left[\mathrm{F}_{(1-}\right.$ $\left.{ }_{65)}=36,339, p<0.01\right]$.

Tablo 7.

Deney Grubu - Kontrol Grubu Planlama Alt Boyutuna Ait Son Test Puanlarına illişkin ANOVA Sonuçları

\begin{tabular}{|c|c|c|c|c|c|c|}
\hline Varyansın Kaynağı & KT & & sd & KO & $\mathbf{F}$ & p \\
\hline Deneklerarası & 23,512 & 66 & & & & \\
\hline Grup (Birey/Grup) & 1,773 & & 1 & 1,773 & 5,303 & 0,025 \\
\hline Hata & 21,739 & & 65 & 0,334 & & \\
\hline Denekleriçi & 26,786 & 67 & & & & \\
\hline $\begin{array}{l}\text { Ölçüm (Ön test-Son } \\
\text { test) }\end{array}$ & 7,221 & & 1 & 7,221 & 38,330 & 0,000 \\
\hline Grup*Ölçüm & 6,471 & & 1 & 6,471 & 32,124 & 0,000 \\
\hline Hata & 13,094 & & 65 & 0,201 & & \\
\hline Toplam & 50,298 & 133 & & & & \\
\hline
\end{tabular}

Tablo 7'de "Öykü Yazma Becerisi Ölçeği" planlama alt boyutuna ait son test puanlarına ait bulgular görülmektedir. Bu bulgulara göre deney grubunda yer alan öğrencilerin planlama boyutu son test puanları ile kontrol grubunda yer alan öğrencilerin son test puanları arasında anlamlı düzeyde fark vardır $\left[F_{(1-65)}=32,124, p<0.01\right]$. Bu farkın deney grubunda yer alan öğrencilerin lehine olduğu görülmektedir.

Tablo 8.

Deney Grubu - Kontrol Grubu Mekân Alt Boyutuna Ait Son Test Puanlarına ilişkin ANOVA Sonuçları

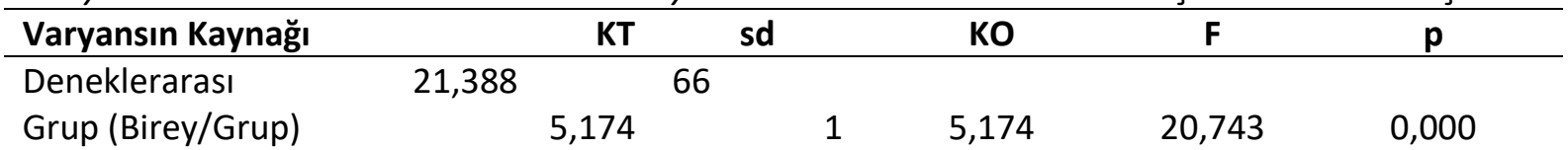




\begin{tabular}{lrrrrrr} 
Hata & \multicolumn{2}{c}{16,214} & 65 & 0,249 & & \\
\hline $\begin{array}{l}\text { Denekleriçi } \\
\text { Ölçüm (Ön test-Son }\end{array}$ & $\mathbf{2 9 , 7 1 5}$ & 67 & & & & \\
test) & 12,759 & & 1 & 12,759 & 64,822 & 0,000 \\
$\begin{array}{l}\text { Grup*ölçüm } \\
\text { Hata }\end{array}$ & $\mathbf{4 , 1 6 2}$ & & $\mathbf{1}$ & $\mathbf{4 , 1 6 2}$ & $\mathbf{2 1 , 1 4 3}$ & $\mathbf{0 , 0 0 0}$ \\
Toplam & 12,794 & & 65 & 0,197 & & \\
\hline
\end{tabular}

Tablo 8'e göre "Öykü Yazma Becerisi Ölçeği" mekân alt boyutuna ait son test puanları bakımından deney grubunda yer alan öğrencilerin kontrol grubunda yer alan öğrencilere göre istatistiksel olarak anlamlı düzeyde daha fazla gelişim gösterdikleri belirlenmiştir $\left[F_{(1-65)}=21,143\right.$, $\mathrm{p}<0.01]$.

Tablo 9.

Fark Puan Dizilerinin Karşılaştırıldığı ilişskisiz Örneklem t Testi

\begin{tabular}{llllllll}
\hline Alt Boyut & Grubu & $\mathbf{n}$ & $\overline{\mathbf{X}}$ & Ss & sd & $\mathbf{T}$ & $\mathbf{p}$ \\
\hline \multirow{2}{*}{ Karakter } & Deney Grubu & 33 & 0,87 & 0,43 & 65 & 9,345 & 0,000 \\
& Kontrol Grubu & 34 & $-0,02$ & 0,35 & & & \\
\hline \multirow{2}{*}{ Zaman } & Deney Grubu & 33 & 0,84 & 0,90 & 65 & 4,315 & 0,000 \\
& Kontrol Grubu & 34 & $-0,05$ & 0,81 & & & \\
\hline
\end{tabular}

Yukarıdaki tabloda "Öykü Yazma Becerisi Ölçeği” karakter ve zaman alt boyutlarına ait ön test son test puanları arasındaki farklar incelenmiştir. Bu verilere ait bulgular her iki alt boyutta da deney grubunda yer alan öğrencilerin kontrol grubunda yer alan öğrencilere göre anlamlı düzeyde daha fazla gelişim gösterdiklerini belirtmektedir.

Elde edilen bulgular sonucunda toplam puan ve alt boyutlarda yaratıcı yazma etkinliklerinin kullanıldığı deney grubundaki öğrencilerin puan artışının kontrol grubundaki öğrencilerin puanlarını artışına göre anlamlı derecede fazla olduğu görülmüştür.

\section{İkinci Alt Probleme ilişskin Bulgular}

Araştırmanın ikinci alt probleminde deney grubundaki öğrencilerin Öykü Yazma Becerisi Ölçeği ön test ve son test puanları arasında anlamlı bir fark olup olmadığı incelenmiştir. Yapılan analiz sonuçları aşağıdaki tabloda yer almaktadır.

Tablo 10.

Deney Grubu Öğrencilerinin Öykü Yazma Becerisi Ölçeği Ön Test- Son Test Toplam Puanlarına Ilişskin ilişkili Örneklem T Testi Sonuçları

\begin{tabular}{lllllll}
\hline Grubu & $\mathbf{n}$ & $\overline{\mathrm{X}}$ & ss & sd & $\mathbf{T}$ & $\mathbf{p}$ \\
\hline Ön Test & 33 & 1,65 & 0,43 & 32 & $-12,238$ & 0,000 \\
Son Test & 33 & 2,58 & 0,31 & & & \\
\hline
\end{tabular}

Tablo 10 incelendiğinde deney grubu ön test toplam puanları ile son test toplam puanları arasında anlamlı bir fark olduğu belirlenmiştir $\left[\mathrm{t}_{(32)}=-12,238, \mathrm{p}<0.05\right]$. Deney grubundaki öğrencilerin ön test puanlarının aritmetik ortalaması 1,65 iken son test puanlarının 2,58 olduğu görülmektedir. Bu sonuçlar doğrultusunda, yaratıcı yazma etkinliklerinin öğrencilerin öykü yazma becerileri üzerinde etkisi olduğunu söylemek mümkündür.

Deney grubu öğrencilerinin Öykü Yazma Becerisi Ölçeği alt boyutlardan aldıkları puanların ortalamaları arasında anlamlı bir fark olup olmadığı incelenmesi amacıyla yapılan analiz sonuçları Tablo 11 ve Tablo 12 ' de görülmektedir. 
Tablo 11.

Deney Grubu Öğrencilerinin Öykü Yazma Becerisi Ölçeği Içerik, Planlama, Karakter ve Mekân Alt Boyutlarına Ait Ön Test-Son Test Puanlarına Iliş̧kin Ilişskili Örneklem T Testi Sonuçları

\begin{tabular}{llllllll}
\hline Alt Boyut & Grubu & $\mathbf{n}$ & $\overline{\mathbf{X}}$ & $\mathbf{s s}$ & $\mathbf{s d}$ & $\mathbf{T}$ & $\mathbf{p}$ \\
\hline \multirow{2}{*}{ İçerik } & Ön Test & 33 & 1,70 & 0,59 & 32 & $-9,869$ & 0,000 \\
& Son Test & 33 & 2,65 & 0,36 & & & \\
\multirow{2}{*}{ Planlama } & Ön Test & 33 & 1,86 & 0,64 & 32 & $-7,425$ & 0,000 \\
& Son Test & 33 & 2,78 & 0,38 & & & \\
\multirow{2}{*}{ Karakter } & Ön Test & 33 & 1,67 & 0,32 & 32 & $-11,489$ & 0,000 \\
& Son Test & 33 & 2,55 & 0,46 & & & \\
\hline \multirow{2}{*}{ Mekân } & Ön Test & 33 & 1,37 & 0,39 & 32 & $-7,885$ & 0,000 \\
& Son Test & 33 & 2,34 & 0,53 & & & \\
\hline
\end{tabular}

Tablo 12.

Deney Grubu Öğrencilerinin Öykü Yazma Becerisi Zaman Alt Boyutuna Ait Ön Test- Son Test Puanlarına ilişkin Wilcoxon Işaretli Sıralar Testi Sonuçları

\begin{tabular}{lllllll}
\hline Alt Boyut & Sontest-Öntest & $\mathbf{n}$ & $\begin{array}{l}\text { Sıra } \\
\text { Ortalaması }\end{array}$ & Sıra Toplamı & $\mathbf{z}$ & $\mathbf{p}$ \\
\hline \multirow{3}{*}{ Zaman } & Negatif Sıra & 1 & 5,50 & 5,50 & $-3,826$ & 0,000 \\
& Pozitif Sıra & 19 & 10,76 & 204,50 & & \\
& Eşit & 13 & & & & \\
\hline
\end{tabular}

Tablo 11 ve Tablo 12'de yer alan analizler sonucu deney grubu öğrencilerinin Öykü Yazma Becerisi Ölçeği alt boyutlarının tamamında ön test ile son test puanlarının ortalamaları arasında anlamlı bir fark olduğu görülmektedir. Yaratıcı yazma etkinliklerinin öğrencilerin öykü yazma becerilerini içerik, planlama, karakter, mekân ve zaman boyutunda geliştirdiği ifade edilebilir.

\section{Üçüncü Alt Probleme iliş̧kin Bulgular}

Kontrol grubunun Öykü Yazma Becerisi Ölçeği puanlarının ortalamaları arasında anlamlı bir fark olup olmadığına ilişkin analizler Tablo 13, Tablo 14 ve Tablo 15' de belirtilmiştir.

Tablo 13.

Kontrol Grubu Öğrencilerinin Öykü Yazma Becerisi Ölçeği Ön Test- Son Test Toplam Puanlarına Ilişskin ilişskili Örneklem T Testi Sonuçları

\begin{tabular}{lllllll}
\hline Grubu & $\mathbf{n}$ & $\overline{\mathbf{X}}$ & ss & sd & $\mathbf{T}$ & $\mathbf{p}$ \\
\hline Ön Test & 34 & 1,79 & 0,36 & 33 & $-1,850$ & 0,073 \\
Son Test & 34 & 1,90 & 0,24 & & & \\
\hline
\end{tabular}

Yukarıdaki tabloya göre kontrol grubunda yer alan öğrencilerin son test puanlarının ön test puanlarından yüksek olduğu görülmektedir. Ancak kontrol grubunda yer alan öğrencilerin ön test son test toplam puanları arasında anlamlı bir fark olmadığı görülmektedir $\left[\mathrm{t}_{(33)}=-1,850, \mathrm{p}>0.05\right]$.

Tablo 14.

Kontrol Grubu Öğrencilerinin Öykü Yazma Becerisi Ölçeği Içerik, Planlama, Karakter Ve Mekân Alt Boyutlarına Ait Ön Test-Son Test Puanlarına iliş̧kin ilişskili Örneklem T Testi Sonuçları

\begin{tabular}{llllllll}
\hline Alt Boyut & Grubu & $\mathbf{n}$ & $\overline{\mathrm{X}}$ & ss & sd & $\mathbf{T}$ & $\mathbf{p}$ \\
\hline \multirow{2}{*}{ İçerik } & Ön Test & 34 & 1,91 & 0,50 & 33 & $-1,976$ & 0,057 \\
& Son Test & 34 & 2,08 & 0,34 & & & \\
\hline \multirow{2}{*}{ Planlama } & Ön Test & 34 & 2,07 & 0,58 & 33 & $-0,430$ & 0,670 \\
& Son Test & 34 & 2,11 & 0,40 & & & \\
\hline \multirow{2}{*}{ Karakter } & Ön Test & 34 & 1,72 & 0,28 & 33 & 0,486 & 0,630
\end{tabular}




\begin{tabular}{llllllll} 
& Son Test & 34 & 1,69 & 0,31 & & & \\
\hline \multirow{2}{*}{ Mekân } & Ön Test & 34 & 1,33 & 0,34 & 33 & $-2,859$ & 0,007 \\
& Son Test & 34 & 1,60 & 0,57 & & & \\
\hline
\end{tabular}

Tablo 15.

Kontrol Grubu Öğrencilerinin Öykü Yazma Becerisi Ölçeği Zaman Alt Boyutuna Ait Ön Test- Son Test Puanlarına Ilişkin Wilcoxon Işaretli Sıralar Testi Sonuçları

\begin{tabular}{lllllll}
\hline $\begin{array}{l}\text { Alt } \\
\text { Boyut }\end{array}$ & Sontest-Öntest & $\mathbf{n}$ & $\begin{array}{l}\text { Sıra } \\
\text { Ortalaması }\end{array}$ & Sıra Toplamı & z & $\mathbf{p}$ \\
\hline \multirow{3}{*}{ Zaman } & Negatif Sıra & 9 & 8,39 & 75,50 & $-0,421$ & 0,674 \\
& Pozitif Sıra & 7 & 8,64 & 60,50 & & \\
& Eşit & 18 & & & & \\
\hline
\end{tabular}

Kontrol grubunun ön test son test alt boyutlara ilişkin puanların analizi incelendiğinde öykü yazma becerisi ölçeği alt boyutlarından mekân boyutunda öğrencilerin son test puanlarının anlamlı bir şekilde ön test puanlarından yüksek olduğu görülmektedir $\left[\mathrm{t}_{(33)}=-2,859, \mathrm{p}<0.05\right]$. İçerik, planlama, karakter ve zaman alt boyutlarında ise ön test son test puanları arasında anlamlı bir farkın olmadığı görülmüştür. Bu da mevcut öğretim materyallerinde yer alan etkinliklerin içerik, planlama, karakter ve zaman alt boyutlarında öğrencilerin anlamlı bir gelişim göstermelerini sağlamadığı şeklinde ifade edilebilir.

\section{Dördüncü Alt Probleme iliş̧kin Bulgular}

Araştırmanın dördüncü alt probleminde deney grubunda yer alan öğrencilerin ön test ve son test puanları cinsiyet değişkeni kapsamında incelenmiştir. Öğrencilerin son test puanlarının analiz edilmesi için deney ve kontrol grubundaki kız öğrenciler ile erkek öğrencilerin ön test puanlarına ait sonuçlar aşağıdaki tabloda görülmektedir.

Tablo 16.

Deney Grubu Öğrencilerinin Cinsiyet Değişkenine Göre Öykü Yazma Becerisi Ölçeği Ön Test Puanlarının ilişkin Bağımsız Örneklem t Testi Sonuçları

\begin{tabular}{cccccccc}
\hline Alt Boyutlar & Grup & $\mathbf{n}$ & $\overline{\mathbf{X}}$ & ss & sd & $\mathbf{T}$ & $\mathbf{p}$ \\
\hline İçerik & Kız & 19 & 1,88 & 0,66 & 29,781 & 2,352 & 0,026 \\
& Erkek & 14 & 1,45 & 0,38 & & & \\
\hline Planlama & Kız & 19 & 2,05 & 0,71 & 31 & 1,994 & 0,055 \\
& Erkek & 14 & 1,61 & 0,45 & & & \\
\hline \multirow{2}{*}{ Karakter } & Kız & 19 & 1,68 & 0,34 & 31 & 0,141 & 0,889 \\
& Erkek & 14 & 1,66 & 0,32 & & & \\
\hline \multirow{2}{*}{ Mekân } & Kız & 19 & 1,44 & 0,40 & 31 & 1,166 & 0,253 \\
& Erkek & 14 & 1,28 & 0,37 & & & \\
\hline \multirow{2}{*}{ Zaman } & Kız & 19 & 1,26 & 0,56 & 31 & 0,244 & 0,809 \\
& Erkek & 14 & 1,21 & 0,57 & & & \\
\hline Toplam & Kız & 19 & 1,77 & 0,48 & & 2,075 & 0,047 \\
& Erkek & 14 & 1,49 & 0,30 & 30,352 & & \\
\hline
\end{tabular}

Bu sonuçlara göre kız öğrencilerin toplam puan ile içerik alt boyutuna ait puanlarının, erkek öğrencilerin puanlarından anlamlı bir şekilde yüksek olduğu görülmektedir. Bundan dolayı öğrencilerin Öykü Yazma Becerisi Ölçeği son test toplam puanları ANCOVA ile analiz edilmiştir. İçerik alt boyutuna ait son test puanları ise gerekli varsayımları sağlamadığından dolayı fark puanların t testi ile analiz edilmiştir. Planlama, karakter, mekân ve zaman alt boyutlarında ise kız öğrenciler ile erkek öğrencilerin ön test puanları arasında anlamlı bir fark görülmemiştir. Bu alt boyutlara ait son test puanları bağımsız 
örneklem t testi ile analiz edilmiştir. Deney grubunda yer alan öğrencilerin cinsiyet değişkenine göre son test puanlarına ait sonuçlar Tablo 17, Tablo 18, Tablo 19 ve Tablo 20' de görülmektedir.

Tablo 17.

Deney Grubu Öğrencilerinin Cinsiyet Değişkenine Göre Öykü Yazma Becerisi Ölçeği Son Test Toplam Puanlarına ilişskin Ortalama ve Standart Sapma Değerleri

\begin{tabular}{ccccc}
\hline & Cinsiyet & $\mathbf{n}$ & $\bar{X}$ & Düzeltilmiş Ortalama \\
\hline \multirow{2}{*}{ Toplam Puan } & Kiz & 19 & 2,65 & 2,63 \\
& Erkek & 14 & 2,47 & 2,51 \\
\hline
\end{tabular}

Tablo 18.

Deney Grubu Öğrencilerinin Cinsiyet Değişkenine Göre Öykü Yazma Becerisi Ölçeği Son Test Toplam Puanlarına ilişskin ANCOVA Sonuçları

\begin{tabular}{llccccc}
\hline & $\begin{array}{l}\text { Varyansın } \\
\text { Kaynağı }\end{array}$ & KT & sd & KO & F & p \\
\hline \multirow{3}{*}{ Toplam Puan } & Ön Testler & 0,291 & 1 & 0,291 & 3,221 & 0,083 \\
& Grup & $\mathbf{0 , 0 9 7}$ & $\mathbf{1}$ & $\mathbf{0 , 0 9 7}$ & $\mathbf{1 , 0 7 7}$ & $\mathbf{0 , 3 0 8}$ \\
& Hata & 2,706 & 30 & 0,090 & & \\
& Toplam & 223,287 & 33 & & & \\
\hline
\end{tabular}

Illgili analiz sonucunda düzeltilmiş başarı puanları ortalamaları arasında bir fark olmadığı görülmektedir $\left[F_{(1-30)}=1,077, p>0,05\right]$. Bu durum yaratıcı yazma etkinliklerinin kız ve erkek öğrenciler üzerinde benzer bir etkiye sahip olduğunu göstermektedir.

Tablo 19.

Deney Grubu Öğrencilerinin Cinsiyet Değişkenine Göre Öykü Yazma Becerisi Ölçeği Planlama, Karakter, Mekân ve Zaman Alt Boyutlarına Ait Son Test Puanlarına Iliş̧kin Bağımsız Örneklem t Testi Sonuçları

\begin{tabular}{cccccccc}
\hline Alt Boyutlar & Grup & $\mathbf{n}$ & $\bar{X}$ & ss & sd & T & p \\
\hline Planlama & KIz & 19 & 2,82 & 0,32 & 31 & 0,627 & 0,535 \\
& Erkek & 14 & 2,73 & 0,47 & & & \\
\hline Karakter & KIz & 19 & 2,63 & 0,44 & 31 & 1,098 & 0,281 \\
& Erkek & 14 & 2,45 & 0,48 & & & \\
\hline Mekân & KIz & 19 & 2,42 & 0,53 & 31 & 0,901 & 0,375 \\
& Erkek & 14 & 2,25 & 0,54 & & & \\
\hline Zaman & KIz & 19 & 2,15 & 0,89 & 31 & 0,504 & 0,618 \\
& Erkek & 14 & 2,00 & 0,87 & & & \\
\hline
\end{tabular}

Tablo 20.

Deney Grubu Öğrencilerinin Cinsiyet Değişkenine Göre Öykü Yazma Becerisi Ölçeği İçerik Alt Boyutuna Ait Ön Test-Son Test Puanlarının Farklarına Iliş̧kin Bağımsız Örneklem t Testi Sonuçları

\begin{tabular}{cccccccc}
\hline & Grup & $\mathbf{n}$ & $\bar{X}$ & ss & sd & $\mathbf{T}$ & $\mathbf{p}$ \\
\hline içerik & KIz & 19 & 0,86 & 0,63 & 31 & $-0,973$ & 0,338 \\
& Erkek & 14 & 1,05 & 0,40 & & & \\
\hline
\end{tabular}

Alt boyutlara ait puanlar incelendiğinde öykü yazma becerisi ölçeği içerik, planlama, karakter, mekân ve zaman alt boyutlarının tamamında deney grubundaki kız ve erkek öğrencilerin puanları arasında anlamlı bir fark olmadığı belirlenmiştir. Bu sonuç yaratıcı yazma etkinliklerinin kız ve erkek öğrencilerin öykü yazma becerilerinde anlamlı bir farklılı̆a yol açmadığını ortaya koymaktadır. 


\section{Tartışma ve Sonuç}

Araştırmada deney grubu ile kontrol grubunun Öykü Yazma Becerisi Ölçeği toplam puanları ve alt boyutlardan aldıkları ön test puanlarının ortalamaları arasında anlamlı bir fark olmadığı belirlenmiştir. Bu durum deney grubunda yer alan öğrenciler ile kontrol grubunda yer alan öğrencilerin uygulama öncesinde öykü yazma becerileri bakımından birbirlerine benzer durumda olduklarını göstermektedir.

Öykü Yazma Becerisi Ölçeği son testten alınan puanların ortalamaları incelendiğinde deney grubu ile kontrol grubu arasında deney grubu lehine anlamlı bir fark olduğu görülmüştür. Yaratıcı yazma etkinliklerinin farklı sınıf düzeylerine göre farklı değişkenler açısından incelendiği araştırmalar mevcuttur. Ortaokul düzeyinde yapılan bu araştırmaların büyük bir bölümünde yaratıcı yazma etkinliklerinin öğrencilerin yazılı anlatım becerilerini geliştirdiği görülmektedir (Ak, 2011; Beydemir, 2010; Duran, 2010; Erdoğan, 2012; Korkmaz, 2015; Öztürk, 2007). Yapılan bu araştırmalarda 7. sınıf düzeyinde çalışma olmadığı görülmüştür. 7. sınıf düzeyinde yapmış olduğumuz bu araştırmanın sonuçlarının diğer sınıf düzeyinde yapılmış olan çalışmalarda elde edilen sonuçlarla örtüştüğü söylenebilir.

Öykü yazma becerisi alt boyutları ele alındığında, içerik, planlama, karakter, mekân ve zaman alt boyutlarında deney grubu öğrencileri ile kontrol grubu öğrencilerinin son test puanlarııın ortalamaları arasında anlamlı bir fark olduğu belirlenmiştir. Bu durum yaratıcı yazma etkinliklerinin, öğrencilerin öykü elementlerinin tamamında yazma becerilerini geliştirdiğini göstermektedir.

Deney grubu ile kontrol grubunda yer alan öğrencilerin kendi içlerinde uygulama öncesi ve sonrası aldıkları puanlar karşılaştırılmıştır. Deney grubu öğrencilerinin Öykü Yazma Becerisi Ölçeği toplam puan ile içerik, planlama, karakter, mekân ve zaman alt boyutlarına ön test ve son test puanlarının ortalamaları arasında anlamlı bir fark olduğu görülmüştür. Bu durum deney grubunda yer alan öğrencilerin gelişiminin istatistiksel olarak anlamlı olduğunu belirtmektedir. Kontrol grubunda bulunan öğrencilerin ise mevcut materyallerde yer alan etkinliklerle yürütülen dersler sonucunda Öykü Yazma Becerisi Ölçeği toplam puanları ile içerik, planlama, karakter ve zaman alt boyutlarında ön test son test puanlarının ortalamaları arasında istatistiksel olarak anlamlı bir fark olmadığı belirlenmiştir. Alt boyutlardan mekân alt boyutunda ise kontrol grubunda yer alan öğrencilerin ön test son test puanlarının ortalamaları arasında anlamlı bir farka rastlanmıştır. Bu sonuçlar doğrultusunda yaratıcı yazma etkinliklerinin 7. sınıf öğrencilerinin öykü yazma becerilerini geliştirdiği ifade edilebilir.

Cinsiyet değişkeni bakımından yaratıcı yazma uygulamalarının, öğrencilerin Öykü Yazma Becerisi Ölçeği alt boyutları ile toplam puanları üzerinde anlamlı bir etkisi olmadığı görülmüştür. Bu sonuçlar yaratıcı yazma etkinliklerinin hem kız hem de erkek öğrencilerin öykü yazma gelişimlerini benzer düzeyde etkilediğini göstermektedir. Ulu'nun (2019), 4. sınıf öğrencilerinin yaratıcı yazma ve öykü öğelerini değerlendirdiği çalışmasında cinsiyet değişkenine göre kız öğrenciler lehine anlamlı bir farklılık görülmüştür. Bununla birlikte bazı araştırmalarda öğrencilerin öyküleyici metin yazma becerileri bakımından kız ve erkek öğrenciler arasında bir farklılık olmadığı sonucuna varılmıştır (Kılıç, 2012; Yasul, 2014; Yılmaz, 2008; Coşkun, 2006). Çalışmamızda elde ettiğimiz sonuçlar, yapılan araştırmaların büyük bir bölümü ile benzerlik gösterir niteliktedir.

Yapılan çalışmalar yaratıcı yazma çalışmalarının öğrencilerin yazmaya yönelik tutumlarını da olumlu etkilediğini göstermektedir (Susar Kırımızı, 2009; Beydemir, 2010; Erdoğan, 2012; Korkmaz, 2015). Ayrıca Avcı (2013) yaptığı araştırmada yaratıcı yazma etkinliklerinin 8. sınıf öğrencilerinin yazma eğilimlerini olumlu yönde etkilediğini belirlemiştir. Bu durumun da öğrencilerin yazma becerilerini geliştirmelerinde etkisi büyüktür.

Bu bağlamda ortaokul düzeyindeki öğretim materyallerinde yaratıcı yazma etkinliklerine daha fazla yer verilmesinin öğrencilerin yazma becerilerini geliştirmelerinde faydalı olabileceği söylenebilir.

Yaratıcı yazma etkinliklerine yönelik farklı metin türleri kapsamında ele alınabilecek çalışmaların planlanması ve boylamsal çalışmaların yapılması bu konuda daha kapsamlı sonuçlar elde edilmesini sağlayabilir. Bununla birlikte öğretim materyallerinde farklı metin türlerine yönelik yaratıcı yazma etkinliklerine yer verilmesi, öğrencilerin yazma becerilerini geliştirmelerine katkı sağlaması bakımından daha etkili bir öğretim sürecinin gerçekleşmesine yol açabilir. 


\section{Araştırma ve Yayın Etiği}

Bu çalışmada "Yükseköğretim Kurumları Bilimsel Araştırma ve Yayın Etiği Yönergesi" kapsamında uyulması belirtilen tüm kurallara uyulmuştur. Yönergenin ikinci bölümü olan "Bilimsel Araştırma ve Yayın Etiğine Aykırı Eylemler" başlığı altında belirtilen eylemlerden hiçbiri gerçekleştirilmemiştir.

\section{Yazarların Katkı Oranı}

Makalede 1. yazar $\% 60,2$. yazar $\% 40$ oranında katkı düzeyine sahiptir.

\section{Çıkar Çatışması}

Yazarlar arasında çıkar çatışmasına teşkil edebilecek herhangi bir durum yoktur.

\section{Kaynaklar}

Ak, E. (2011). Yaratıcı yazma tekniklerinin ilköğretim 5. sınıf öğrencilerinin Türkçe dersindeki yazıı anlatım becerileri üzerindeki etkisi (Yayımlanmamış yüksek lisans tezi). Dokuz Eylül Üniversitesi Eğitim Bilimleri Enstitüsü, İzmir.

Akdal, D. (2011). Metinler arası okuma yaklaşımının ilköğretim beşinci sınıf öğrencilerinin yaratıcı yazma becerilerine etkisi (Yayımlanmamış yüksek lisans tezi). Ahi Evran Üniversitesi Sosyal Bilimler Enstitüsü, Kırşehir.

Aktaş, M. (2009). Yabancı dil öğretiminde yaratıcı yazmanın başarıya ve yazılı anlatıma etkisi (Yayımlanmamış doktora tezi). Ankara Üniversitesi Sosyal Bilimler Enstitüsü, Ankara.

Aslan, E. (2001). Kavram boyutunda yaratıcılık. Türk Psikolojik Danışma ve Rehberlik Dergisi, 2(16), 1521.

Aşılıoğlu, B. (1993). Ortaokullarda Türkçe öğretimi (Yayımlanmamış doktora tezi). Ankara Üniversitesi Sosyal Bilimler Enstitüsü, Ankara.

Avcı, A. S. (2013). Yaratıcı yazma etkinliklerinin 8. sınıf öğrencilerinin yazma eğilimleri ve yazma kaygılarına etkisi (Yayımlanmamış yüksek lisans tezi). Niğde Üniversitesi Eğitim Bilimleri Enstitüsü, Niğde.

Beydemir, A. (2010). Illköğretim 5. sınıf Türkçe dersinde yaratıcı yazma yaklaşımının yazmaya yönelik tutumlara, yaratıcı yazma ve yazma erişisine etkisi (Yayımlanmamış yüksek lisans tezi). Pamukkale Üniversitesi Sosyal Bilimler Enstitüsü, Denizli.

Bulut, K. (2012). 2006 Türkçe Dersi (6, 7, 8. sınıflar) Öğretim Programı'nda yer alan yazma kazanımlarının yaratıcı yazmaya uygunluğu (Yayımlanmamış yüksek lisans tezi). Yüzüncü Yıl Üniversitesi Sosyal Bilimler Enstitüsü, Van.

Burksaitiene, N. (2014). Creative writing at the university: Students' perception and expectation. Socialiniu Mokslu Studijos Societal Studies, 6(3), 661-671.

Büyüköztürk, Ş., Kılıç Çakmak, E., Akgün, Ö. E., Karadeniz, Ş. ve Demirel, F. (2016). Bilimsel araştırma yöntemleri. Ankara: Pegem Akademi.

Colantone, L., Cunnigham-Wetmore, M. and Dreznes, J. (1998). Improwing creative writing. Research project reports, Saint Xavier University, Chicago.

Coşkun, í. (2006), ilköğretim 5. sınıf öğrencilerinin kompozisyon yazma becerileri üzerine bir araştırma (Yayımlanmamış yüksek lisans tezi). Marmara Üniversitesi Eğitim Bilimleri Enstitüsü, İstanbul.

Çoban, A. (2012). Illköğretim 7. sını öğrencilerinin oluşturdukları öyküleyici metinlerin bağdaşıklık ve tutarlıık ölçütlerine göre değerlendirilmesi (Yayımlanmamış yüksek lisans tezi). Erciyes Üniversitesi Ĕgitim Bilimleri Enstitüsü, Kayseri.

Dalavi, A. ve Deshpande, S. C. (2018). A critical study of role of creative writing skills in improving academic performance of school children. Vol - V Issue- IV APRIL 2018 ISSN 2349-638x Impact Factor 4.574.

Davaslıgil, Ü. (1994). Yüksek gizli güce sahip lise öğrencilerinin yaratıcılıkları üzerine bir deneysel araştırma. M.Ü. Atatürk Eğitim Fakültesi Eğitim Bilimleri Dergisi, 6, 53-68.

Donovan, M. (2012). Adventures in writing-101 creative writing exercise. San Francisco: Swan Hatch Press. 
Duran, S. (2010). Yaratıcı yazma yaklaşımının yazılı anlatım becerisinin gelişimine etkisi (Yayımlanmamış yüksek lisans tezi). Trakya Üniversitesi Sosyal Bilimler Enstitüsü, Edirne.

Duru, A. (2014). Altıncı sınıf öğrencilerinin yaratıcı yazma becerilerini geliştirmeye yönelik stratejilerin etkililiğin değerlendirilmesi (Yayımlanmamış yüksek lisans tezi). Niğde Üniversitesi Eğitim Bilimleri Enstitüsü, Niğde.

Erdoğan, Ö. (2012). Süreç temelli yaratıcı yazma uygulamalarının yazılı anlatım becerisine ve yazmaya ilişkin tutuma etkisi (Yayımlanmamış doktora tezi). Hacettepe Üniversitesi Sosyal Bilimler Enstitüsü, Ankara.

Fraenkel, J. R; Wallen, Norman ve Hyun, Helen H. (2012). How to design and evaluate research in education. San Francisco. Mc Graw Hill Publication.

Fyle B (1985). Encouraging creative thinking in children. Teacher Educ. Q., 12: 1.

George, D. ve Mallery, P. (2020). IBM SPSS statistics 26 step by step - a simple guide and referance. New York: Routledge.

Göğüş, B. (1978). Orta dereceli okullarımızda Türkçe ve yazın eğitimi. Ankara: Gül Yayınevi.

İpşiroğlu, Z. (2006). Yaratıcı yazma - yaratıcı yazma çalışmalarında yazınsal metinlerin işlevi. İstanbul: Morpa.

Kale, N. (1993), Üç düşünsel yeti: eleştirel düşünme, yaratıcı düşünme, problem çözme. Yaşadıkça Eğitim Dergisi, Mayıs-Haziran, 24- 27.

Kan, A. (2018). Ölçme araçlarında bulunması gereken nitelikler. H. Atılgan (Ed.), Eğitimde ölçme ve değerlendirme içinde (s. 43-102). Ankara: Anı Yayıncılık.

Karakuş, M. (2001). Eğitim ve yaratıcılık. Eğitim ve Bilim, 26(119), 3-7.

Kılıç, B. (2012). Illköğretim yedinci sınıf öğrencilerinin yazdıkları öyküleyici metinler üzerine bir inceleme (Yayımlanmamış yüksek lisans tezi). Necmettin Erbakan Üniversitesi Eğitim Bilimleri Enstitüsü, Konya.

Korkmaz, G. (2015). Yaratıı yazma yönteminin 6. sınıf öğrencilerinin yazma öz yeterlik algılarına, yazmaya ilişkin tutumlarına ve yazma becerisi akademik başarılarına etkisi (Yayımlanmamış yüksek lisans tezi). Gaziantep Üniversitesi Eğitim Bilimleri Enstitüsü, Gaziantep.

Küçük, S. (2020). Yazııı anlatım ve yaratıcılık. Ankara: Gece Kitaplığı.

Maltepe, S. (2006). Yaratıcı yazma yaklaşımı açısından Türkçe derslerindeki yazma süreçlerinin ve ürünlerinin değerlendirilmesi (Yayımlanmamış doktora tezi). Ankara Üniversitesi Sosyal Bilimler Enstitüsü, Ankara.

May, S. (2013). Yaratıcı yazarlık (F. Yanık, Çev.). İstanbul: Optimist Yayınları.

Morley, D. (2010). The cambridge introduction to creative writing. İndia: Cambridge University Press.

Myers, D. G. (1993). The rise of creative writing. Journal of the History of Ideas, 54(2), 277-297.

Oral, G. (2014). Yine yazı yazıyoruz. Ankara: Pegem Akademi.

Öztürk, E. (2007). Illköğretim beşinci sınıf öğrencilerinin yaratıcı yazma becerilerinin değerlendirilmesi (Yayımlanmamış doktora tezi). Gazi Üniversitesi Eğitim Bilimleri Enstitüsü, Ankara.

Sönmez, V. (2017). Öğretim ilke ve yöntemleri. Ankara: Anı Yayıncılık.

Sundt, E. (2018). Teachers' beliefs on creative writing in english language teaching in norway (Master's Thesis). Inland Norway University Faculty of Educational Sciences.

Susar Kırmızı, F. ve Beydemir, A. (2012). İlköğretim 5. sınıf Türkçe dersinde yaratıcı yazma yaklaşımının yazmaya yönelik tutumlara etkisi. Ahi Evran Üniversitesi Kırşehir Eğitim Fakültesi Dergisi, 13 (3), 319-337.

Susar Kırmızı, F. (2009). Türkçe dersinde yaratıcı drama yöntemine dayalı yaratıcı yazma çalışmalarının yazmaya yönelik tutuma etkisi. Yaratıcı Drama Dergisi, 4(7), 51-67.

Temizkan, M. (2010). Türkçe öğretiminde yaratıcı yazma becerilerinin geliştirilmesi. TÜBAR-XXVII Bahar, 621-643.

Temizkan, M. (2011). Yaratıcı yazma etkinliklerinin öykü yazma becerisi üzerindeki etkisi. Kuram ve Uygulamada Eğitim Bilimleri, 11(2), 919-940.

Yasul, A. F. (2014). illkokul 4. sınıf öğrencilerinin öyküleyici metin yazma becerilerinin değerlendirilmesi (Yayımlanmamış yüksek lisans tezi). İnönü Üniversitesi Ĕgitim Bilimleri Enstitüsü, Malatya. 
Yılmaz, Ö. (2012). 11. sınıf öğrencilerine ait öyküleyici metinlerin bağdaşıklık ve tutarlılı açısından incelenmesi (Yayımlanmamış yüksek lisans tezi). Bülent Ecevit Üniversitesi Sosyal Bilimler Enstitüsü, Zonguldak.

Yılmaz, S. K. (2008). Illköğretim altıncı sınıf öğrencilerinin öyküleyici metin yazma becerileri (Yayımlanmamış yüksek lisans tezi). Gazi Üniversitesi Eğitim Bilimleri Enstitüsü, Ankara.

Ulu, H. (2019). Investigation of fourth grade primary school students' creative writing and story elements in narrative text writing skills. International Journal of Progressive Education, 15(5), 273-287.

Ün Açıkgöz, K. (2014). Aktif öğrenme. İzmir: Biliş Yayınları.

\section{Introduction}

\section{Extended Abstract}

The notion of creativity is considered as a skill that exists in individuals and can be improved. It is of great importance that this skill is acquired by individuals at an early age. It is possible to provide the most suitable environment for this in educational institutions. Developing the notion of creativity in language education, as well as in other learning areas, is an element that will allow students to develop in many ways. The notion of creativity should be addressed within the scope of writing skills, which is one of the language skills.

The notion of creativity has been emphasized after the constructivist approach has been adopted in our country. With this understanding, creativity has become one of the learning outcomes in the curriculum. This situation has also been handled within the scope of Turkish education program. Thus, creative writing has gained importance. The aim of this study is to examine the effect of creative writing activities on 7th grade students' story writing skills.

\section{Method}

In this study, the pre-test post-test control group design was used. The research sample includes 67 students who were 7th grader in a secondary school in Antakya/Hatay in the 2019-2020 academic year. There were 33 students in the experimental group and 34 students in the control group. In the study, which was conducted for 12 weeks, while the lessons were carried out with creative writing activities in the experimental group, the teaching was continued with the existing textbook activities in the control group. For the pre-test and post-test, the students were asked to write a story about one of the story topics determined. The pre-test and post-tests of the students in the experimental and control groups were evaluated in line with the Story Writing Skills Scale Results. In the analysis of the data, $t$ test, Two-Way ANOVA for for Mixed Measures, Wilcoxon Signed Ranks Test, Mann Whitney $U$ Test and ANCOVA tests were used.

\section{Result and Discussion}

In the study, it was determined that there was no significant difference between the total scores of the Story Writing Skills Scale of the experimental group and the control group and the averages of the pre-test scores they got from the sub-dimensions. This indicates that the students in the experimental group and the students in the control group were similar to each other in terms of story writing skills before the implementation.

When the average scores of the Story Writing Skills Post-test were examined, it was seen that there was a significant difference in favor of the experimental group between the experimental group and the control group. Considering the story writing skill sub-dimensions, it was determined that there is a significant difference between the post-test scores of the experimental group students and the control group students in the content, planning, character, place and time sub-dimensions.

The scores of the students in the experimental group and the control group before and after the application were compared. It was observed that there was a significant difference between the total score of the Story Writing Skills Scale of the experimental group students and the averages of the pre-test and post-test scores of the sub-dimensions of content, planning, character, place and time. This situation indicates that the development of the students in the experimental group is statistically 
significant. It was concluded that there was a similar improvement in the story writing success of female students and male students in the experiment group. It was determined that there was no statistically significant difference between the total scores of the Story Writing Skills Scale and the pretest post-test scores in content, planning, character and time sub-dimensions as a result of the lessons conducted with the activities in the existing materials of the students in the control group. In the subdimension of place sub-dimension, a significant difference was found between the mean pre-test posttest scores of the students in the control group. In most of the studies conducted at the secondary school level, it is seen that creative writing activities improve students' written expression skills (Ak, 2011; Beydemir, 2010; Duran, 2010; Erdoğan, 2012; Korkmaz, 2015; Öztürk, 2007).

The findings show that creative writing activities improve the story writing skills of seventh grade students. It was determined that students were more successful in the sub-dimensions of story writing skill, content, planning, character, place and time. In line with these results, it can be said that giving more place to creative writing activities in teaching materials at secondary school level may be beneficial for students to improve their writing skills. 